\title{
TEORI MAKNA DALAM STRUKTUR LINGUISTIK ARAB PERSPEKTIF MUFASIR MASA KLASIK
}

\author{
Ahmad Atabik \\ Institut Agama Islam Negeri Kudus \\ Email: atabik@iainkudus.ac.id
}

\begin{abstract}
This article aims to examine the theory of meaning in the structure of Arabic linguistics that is studied by classical era commentators. In the classical era, the study that became a concentration of the study of al-Qur'an is the understanding of the meaning of the Qur'an with Arabic linguistic approach. To get the ideal meaning from the verses of the Koran they pay attention to i'rab (Arabic grammar). They are concerned in the field of language criticism through grammatical, stylistic and semantic approaches. Theories of meaning in classical times are supported by various works of classical Arabic linguists entitled Ma'ānī al-Qur'ān, al-Farrā ', al-Kisā'̄, alZajjäj and al-Nahhhās. These works are very significant in the development of theorization of meaning from the point of view of the structure of the building (grammatical language). Theory of meaning is also supported by the study of stylistics (language style / uslüb). The study of the stylistic al-Qur'an in the theory of meaning is strengthened by al-Jā hiz and al-Jurjānī in their respective works. The final meaning theory can be found in the Qur'anic semantic studies. This study is considered as an ideal method in exposing the meaning of the Qur'anic language. Semantic studies of al-Qur'an are supported by the theory of al-wujūh wa al-nazāirir and siyāq (the context of meaning of language). The study of the Wujūh and Nazāir is a method of understanding the message of meaning which is possessed by the verses of the verses of the Qur'an, once studied by Ibn al-Jauzì. While siyāq is an indicator used in determining the meaning desired by mutakallim, it has been studied by Ibn Daqīq al'Id.
\end{abstract}

Keywords: Meaning theory, Arabic linguistics, mufassir, classical period

\section{A. Pendahuluan}

Sebagaimana diwahyukan Allah dalam kitab suci-Nya, al-Qur'an turun dengan berbahasa Arab (QS. Yusuf: 2, QS. al-Syu'ara': 195 dan alZumar: 28). Hal ini dilandasi bahwa semua kitab suci yang pernah disampaikan kepada para nabi-Nya menggunakan bahasa masyarakatnya 
(QS. Ibrahim: 4). Nabi Muhammad adalah orang Arab hidup pada masyarakat Arab, maka al-Qur'an turun dengan bahasa Arab. Dengan kata lain, sosio-geografis turunnya al-Qur'an ialah menggunakan bahasa Arab, karena Nabi Muhammad orang Arab dan penerima wahyu al-Qur'an juga masyarakat Arab. Ini berarti bahwa syarat utama untuk memahami makna dari pelbagai pesan al-Qur'an adalah pengetahuan tentang bahasa Arab.

Al-Qur'an turun menggunakan kosakata yang dipergunakan oleh masyarakat Arab, kendati sifat al-Qur'an sangat nampak berbeda dengan sifat bahasa Arab yang biasa dipergunakan oleh komunitas Arab ketika alQur'an diturunkan. Bahasa Arab yang digunakan komunitas Arab pada waktu itu merupakan bahasa yang disusun oleh mereka dengan pelbagai sifat-sifatnya. ${ }^{1}$ Sementara, bahasa al-Qur'an yang berbahasa Arab adalah kalam Allah, yang serupa pada tataran kefasihan dan keindahan sastranya (QS. al-Zumar: 23). Al-Qur'an bukan syi'ir, bukan puisi, dan bukan prosa layaknya bahasa yang disusun dan dipahami maknanya oleh masyarakat Arab. $^{2}$

Dari sini bisa dinyatakan bahwa tidak semua ayat al-Qur'an dengan serta merta bisa mudah dipahami oleh masyarakat Arab, sebab dalam alQur'an ada bagian-bagian yang sulit dipahami. Seperti ayat-ayat mutāsyabihāt (ayat-ayat yang samar pengertiannya). Di dalam al-Qur'an juga terdapat lafaz musytarak (lafal yang mempunyai makna ganda), altaqdìm wa al-ta'khīr (lafal yang didahulukan dan diakhirkan), gharābah al-lafzhī (lafal yang masih asing), hadzf (pembuangan kata) dan lain sebagainya. ${ }^{3}$ Aspek-aspek kajian bahasa Arab yang sangat varian dalam mendekati kajian makna al-Qur'an inilah yang menjadi titik fokus oleh para mufassir era klasik atau abad pertama dan paruh kedua abad kedua hijriah.

Pada era klasik para mufassir dan pengkaji al-Qur'an menitik beratkan kajian linguistik Bahasa Arab yang tercurah pada i'rab

${ }_{1}^{1}$ Abdul Mustaqim, "Teori Hudud Muhammad Syahrur dan Kontribusinya dalam Penafsiran al-Qur'an," AL QUDS: Jurnal Studi Alquran dan Hadis 1, no. 1 (2017): 1-26.

${ }^{2}$ M. Quraish Shihab, Kaidah Tafsir: Syarat, Ketentuan, dan Aturan yang Patut Anda Ketahui dalam Memahami Ayat-ayat al-Qur'an (Tangerang: Lentera Hati, 2013), 36.

3 Nor Ichwan, Memahami Bahasa al-Qur'an: Refleksi atas Persoalan Linguistik (Yogyakarta: Pustaka Pelajar, 2002), x. 
(gramatika bahasa Arab) dan masalah redaksional ayat. ${ }^{4}$ Pada era itu juga muncul pengembangan keilmuan yang signifikan dalam stadium embrional penafsiran al-Qur'an dengan pendekatan kritik bahasa (linguistik). Era itu juga ditandai banyak karya mufasir dan pengkaji alQur'an yang menitiktekankan pada aspek-aspek makna lafaz al-Qur'an, baik secara gramatika, stilistik maupun semantik. ${ }^{5}$ Oleh sebab itu, artikel ini berupaya menggali teori makna dalam ruang lingkup struktur linguistik perspektif kajian al-Qur'an oleh mufasir masa klasik. Selanjutnya, artikel ini dalam metode pengumpulan datanya menggunakan metode dokumentasi dan dianalisis secara deskriptifkritis.

\section{B. Kajian Al-Qur'an dan Linguistik Arab Masa Klasik}

Al-Żahabī membagi perkembangan pemikiran tafsir pada masa klasik dalam tiga tahap. Pertama, tafsir al-Qur'an pada era Nabi dan sahabat. Kedua, tafsir pada era tabi'in dan, ketiga tafsir pada era pembukuan (kodifikasi). Pada kodifikasi ini berakhir sampai berakhirnya abad II Hijriyah. ${ }^{6}$ Basūnī Faudah menjelaskan bahwa pada era ini kajian tafsir senantiasa dipengaruhi oleh kajian-kajian berupa riwayat. Selain itu muncul penafsiran yng berasal dari orang-orang Nasrani dan Yahudi yang menjadi muallaf. Penafsiran ini disebut dengan nasrāniyyāt dan isrāiliyyāt. Para era ini bahkan era berikutnya juga timbul kontroversi yang perselisihan pendapat yang tajam seputar penafsiran ayat-ayat yang berhubungan dengan masalah akidah. ${ }^{7}$

Menurut Quraish Shihab karakteristik penafsiran pada masa klasik ini terletak pada metode periwayatan (ma'sür) dan kebahasaan (linguistik). ${ }^{8}$ Hal ini bisa dilihat dari munculnya mufasir pertama, al-

4 Mahmud Basuni Faudah, Tafsir-Tafsir al-Qur'an: Perkenalan dan Metodologi Tafsir. terj. Mokhtar Zoerni dan Abdul Qadir Hamid. (Bandung: Penerbit Pustaka, 1987), 60.

${ }^{5}$ M. Nur Kholis Setiawan, Akar-Akar Pemikiran Progresif dalam Kajian al-Qur'an (Yogyakarta: Elsaq Press, 2008), 63.

${ }^{6}$ Muhammad Husain Al-Żahabī, Al-Tafsìr wa al-Mufassirūn, vol. 1 (Cairo: Maktabah Wahbah, 1995), 18.

7 Ahmad Atabik, "Corak Tafsir Aqidah (Kajian Komparatif Penafsiran Ayat-ayat Aqidah)," ESENSIA: Jurnal Ilmu-Ilmu Ushuluddin 17, no. 2 (2016): 209-23.

${ }^{8}$ Abdurrahman Rusli Tanjung, "Wawasan Penafsiran Alquran dengan Pendekatan Corak Lugawi (Tafsir Lugawi)," Journal Analytica Islamica 3, no. 2 (2014): 333-48. 
Farrā' (w. 207 H) yang pernah mendiktekan hasil penafsirannya kepada murid-muridnya. Tafsir tersebut diberi nama $M a^{\prime} a \bar{n} \bar{i}$ al-Qur'ān, karena tafsir ini lebih kuat pada aspek makna bahasa dalam al-Qur'an ketimbang aspek lainnya. Demikian pula, mufasir klasik semisal al-Ṭabarī dalam karya tafsirnya Jāmi' al-Bayān fi Ta'wīl Ai al-Qur'ān, ia memadukan hasil penafsirannya dua aspek utama yaitu riwayat (ma'sür) dan bahasa (linguistik). ${ }^{9}$

Memang sangat wajar apabila para penafsir masa klasik menekankan penafsirannya pada aspek kebahasaan (linguistik) menimbang era tersebut memang baru maraknya kajian linguistik Arab dan munculnya para pakar linguistik Arab dari berbagai aliran. ${ }^{10}$ Syauqi Dhaif dalam karyanya al-Madaris al-Nahwiyah, membagi aliran dalam linguistik Arab kepada Mazhab Basrah, Kufah, Baghdad, Andalusia, dan Mesir. Perkembangan linguistik Bahasa Arab berasal dari kota Basrah, meluas ke kota Kufah, berlanjut ke Baghdad, Andalusia, dan Mesir. Perbedaan corak linguistik masing-masing kota ini disebabkan oleh geografis masing-masing, sehingga hal ini menyebabkan perbedaan dalam cara berpikir tokoh ahli linguistik Arab (ilmu nahwa atau gramatikal Arab) dalam menyelesaikan permasalahan bahasa Arab. ${ }^{11}$ Lima aliran tersebut mempunyai kecenderungan yang berbeda-beda dalam pemikiran gramatika Arabnya.

Dari kelima aliran ini, aliran Basrah dan Kufah merupakan dua aliran (mazhab) yang paling berpengaruh dalam linguistik Arab, hal ini disebabkan keduanya memerankan independensi dan otoritas yang tinggi. Selain itu, kedua aliran itu juga mempunyai pendukung yang melimpah dan fanatik, sehingga dapat memberi warna pada berbagai aliran berikutnya. ${ }^{12}$ Beberapa tokoh bahasa Arab era klasik dari aliran Basrah adalah Abū al-Aswad al-Dualī (w. $69 \mathrm{H}$ ), peletak dasar kajian ilmu Nahwu (gramatikal Arab), Sibawaih (w. 180 H), ahli bahasa Arab klasik,

${ }_{9}^{9}$ M. Quraish Shihab, Membumikan al-Qur'an (Bandung: Mizan, 1994), 84.

${ }_{10}$ Abd Aziz dan Yuan Martina Dinata, "Bahasa Arab Modern Dan Kontemporer; Kontinuitas Dan Perubahan," Mumtaz: Jurnal Studi Al-Quran dan Keislaman 3, no. 2 (2019): 152-68.

11 M Fathor Rohman, "Kajian Historis; Periodisasi Tokoh Ilmu Nahwu Madzhab Basrah," Ummul Qura 11, no. 1 (2018): 50-72. 2012), 20.

12 Syarif Hidayatullah, Cakrawal Linguistik Arab (Tangerang: al-Kitabah Press, 
membicarakan persoalan fonetik dalam karyanya yang berjudul al-Kitāb. Tokoh lain dari aliran Basrah, Ibnu Jinnī (w. 392 H), menulis karya di bidang fonetik dengan judul Sirr Șinā'ah al-'Arab. ${ }^{13}$

Sementara para tokoh linguistik Arab dari aliran Kufah adalah Abu Ja'far al-Ruasi, ia merupakan tokoh bahasa Arab pertama dari Basrah yang berhasil menyusun kitab tentang tata bahasa Arab, yang kitabnya diberi nama al-Faishal. ${ }^{14}$ Tokoh selanjutnya adalah Ḥamzah al-Kisā'ī (w.189 H), seorang non Arab, salah tokoh ahli Qira'at Sab'ah dan Imam penduduk Kufah dalam bidang linguistik Arab. Sementara, al-Farrā' oleh sebagain kalangan dimasukkan pada aliran Kufah, meskipun ia sangat fanatik dengan keilmuan Imam Sibawaih dalam karyanya. Dari pendalam karya Imam Sibawaih inilah al-Farrā' mampu menelurkan karya yang berjudul Ma'ani al-Qur'an. ${ }^{15}$

Dua aliran tersebut memunculkan banyak perkembangan ilmu linguistik Arab, terutama sintaksis Arab (ilmu nahwu) tradional. Pelopor aliran Mazhab kufah adalah Abu al-Aswad al-Duali, walaupun sementara peneliti menyatakan bahwa al-Khalil bin Ahmad al-Farāhidī (w. $175 \mathrm{H}$ ) merupakan pencetus sintaksis Arab tradisional. Rumus kajian sintaksis inilah yang kemudian digunakan oleh Sibawaih dalam merumuskan kembali sintaksis Arab. Berkat rumusan itu Sibawaih dijuluki sebagai "Perumus Ilmu Nahwu Tradisional" atau sintaksis tradisional. Julukan itu disandang berkat upayanya merumuskan kaidah bahasa Arab yang dituangkan dalam kitabnya yang berjudul al-Kitab, dan terkenal juga dengan istilah "Qur'ān al-Naḥwī". ${ }^{16}$ Dalam kitab tersebut Sibawaih yakin bahwa al-Qur'an merupakan rujukan yang paling lengkap dalam kajian linguistik Arab secara umum dan sintaksis Arab secara khusus.

Sejalan dengan Sibawaih, para tokoh linguistik Arab menyakini bahwa ayat-ayat al-Qur'an merupakan prinsip pokok yang digunakan rujukan dalam kajian rumus-rumus bahasa Arab, linguistik secara umum,

${ }^{13}$ Arifuddin Arifuddin, "PEMIKIRAN-PEMIKIRAN FONETIK IBNU JINNI (W. 392 H./1002 M.)," Jurnal CMES 6, no. 2 (n.d.): 146-63.

${ }^{14}$ Ridwan Ridwan, "Karakteristik Nuhat Kufah Dan Bashrah," LiNGUA: Jurnal Ilmu Bahasa dan Sastra 3, no. 1 (2011).

${ }^{15}$ Abdul Mustaqim, "Tafsir Linguistik (Studi atas Tafsir Ma'anil Qur'an Karya alFarra')," QOF 3, no. 1 (2019): 1-11.

${ }^{16}$ Hidayatullah, Cakrawal Linguistik Arab, 83. 
dan sintaksis secara khusus. Sebab, al-Qur'an merupakan wahyu dengan menggunakan gaya bahasa (uslüb) yang sangat sempurna. Al-Qur'an diturunkan dengan mempergunakan dialek Quraisy, sementara Quraisy merupakan pemilik bahasa Arab yang paling fasih ketika diucapkan. Oleh karena itu, aliran Basrah dalam merumuskan kaidah-kaidah bahasa Arab berprinsip pada ilmu Qira'at, hadis Nabi dan juga perpegang pada syiir Arab tradisional. ${ }^{17}$ Seiring dengan realitas tersebut, kajian pemaknaan terhadap ayat-ayat al-Qur'an era tersebut banyak diwarnai dengan linguistik Arab tradisional sebagai rujukan utama.

\section{Teori Makna dalam Gramatika Bahasa Arab}

Pada era klasik, para tokoh pengkaji al-Qur'an bergumul melakukan upaya-upaya dengan pendekatan struktur makna sebuah lafal dalam gramatikal bahasa untuk memahami makna al-Qur'an. Mereka menyibukkan diri dengan mekanisme pemahaman terhadap makna alQur'an. Berbagai karya para pakar linguistik Arab berjudul Ma'ānī alQur'ān sangat signifikan dalam perkembangan teorisasi makna dari sudut pandang struktuk bangunannya (gramatikal bahasa), mengingat karya dengan judul ini banyak mendiskusikan sisi linguistik al-Qur'an.18 Setidaknya ada 5 (lima) karya berjudul Ma'ani al-Qur'an pada era ini. Ma'ānī al-Qur'ān karya al-Kisā'î (w. 189 H), Ma'ānī al-Qur'ān karya alFarrā' (w. 207 H), Ma'ānī al-Qur'ān karya al-Zajjāj (w. 311), dan Ma'ānī alQur'ān karya al-Naḥhās (w. 338 H).

Karya-karya tokoh ahli bahasa tersebut bukan saja mengulas struktur dalam kalimat al-Qur'an, akan tetapi juga mengkonsep adanya kemungkinan peralihan makna dalam sebuah kosa kata yang dapat berkontribusi pada pengaruh perubahan makna. Dalam pengkajian ini dimungkinkan pula adanya peralihan makna kosa-kata pada makna lain yang bisa dipengaruhi oleh struktur kata dalam sebuah kalimat. Sehingga, argumen lain yang menunjukkan urgensi buah karya para tokoh yang berjudul Ma'ānī al-Qur'ān merupakan fakta bahwa karya-karya tersebut tidak saja terfokus pada gramatika bahasa Arab secara umum, namun

17 'Abd al-'Āl Sālim Mukrim, Al-Qur'ān al-Karīm Wa As̄āruhu fi al-Dirāsāt alNaḥwiyah (Kuwait: Muassasah 'Alī Jarrāḥ al-Ṣabāḥ, 1978), 65.

${ }^{18}$ Setiawan, Akar-Akar Pemikiran Progresif dalam Kajian al-Qur'an, 65. 
juga mengurai kemungkinan perubahan makna yang diakibatkan oleh perubahan struktur kalimat.

Ma'ānì al-Qur'ān karya al-Farrā' merupakan magnum opus dan menjadi rujukan yang otoritatif untuk ilmu gramatika Arab (ilmu Nahwu) aliran Kufah. Karya al-Farrā' juga dinilai oleh pakar bahasa Arab setelahnya sebagai karya tentang kajian lingusitik terhadap al-Qur'an. ${ }^{19}$ Al-Farrā' lebih mementingkan ilmu gramatika Arab terutama pemaknaan kosa kata al-Qur'an daripada disiplin ilmu lain. Dalam memahami makna al-Qur'an al-Farrā' menekankan pada pentingnya menelaah ilmu qira'at, hal ini dilakukan untuk mendapatkan makna yang yang sesuai dengan pemahaman ayat al-Qur'an. Ilmu qira'at bukan hanya sekedar ilmu saja, namun sangat erat hubungannya dengan makna dan kalimat. Oleh karena itu di masa klasik, para pengkaji al-Qur'an dalam menafsirkan corak linguistik, mereka banyak berpegang pada ilmu qira'at tersebut. ${ }^{20}$

Al-Farrā' dalam memahami ayat terkadang menjelaskan kosa kata, terutama pada lafal yang masih samar maknanya, seperti dalam QS. alNisa': 34, wallati takhafuna nusyuzahunna, oleh al-Farrā' kata takhāfüna dimaknai dengan ta'lamūna, berarti menurut al-Farrā' maknanya adalah perempuan-perempuan yang kamu tahu akan nusyuznya. Selanjutnya, ia memberi penjesalan ini seperti dzann (prasangka), dzan seperti ragu, sementara orang yang khawatir terkadang berharap sesuatu. Oleh karena itu, khawatir menyerupai prasangka dan pengetahuan. ${ }^{21}$ Sehingga, alFarrā' selain mengungkap kosa kata, juga menjelaskan argumen kosa kata tersebut.

Dalam memahami makna yang terkandung al-Qur'an, al-Farrā' juga menghubungkannya dengan ilmu qira'at, semisal ketika menafsirkan QS. al-Najm: 32. Allażinna yajtanibūna kabāir al-iśm, al-Farrā' mengatakan Yahya bin Watsab membaca dengan lafal kabir (bukan kabāir), ia mendasarkan bacaan itu dari Abdullah bin Abbas ra. ia sesuai bagi mereka yang membaca kabïr al-ism, dengan kata tunggal (mufrad) bukan jamak (kabāir). Menjelaskan hal ini al-Farrā' menyatakan bahwa kebanyakan

\footnotetext{
${ }^{19}$ Mustaqim, “Tafsir Linguistik (Studi atas Tafsir Ma'anil Qur'an Karya al-Farra').” 2000), 97.

${ }^{20}$ Manī' Abd al-Halīm Mahmūd, Manhaj al-Mufassirīn (Cairo: Dar al-Kitab al-Masri, 1983), 264.

${ }^{21}$ Abū Zakariyā Yahyā bin Ziyād al-Farrā', Ma'ānī al-Qur'ān (Beirut: 'Alam al-Kitab,
} 
orang awam membacanya dengan kabāir al-iśm dengan kata jamak (plural), seolah-olah mengatakan dalam bentuk umum padahal asalnya hanyalah satu. ${ }^{22}$

Tidak beda jauh dengan karya al-Farrā', Ma'ani al-Qur'an karya alZajjāj juga sama-sama menitiktekankan pada makna kosakata ayat alQur'an dalam memahami kalam ilahi ini. Al-Zajjāj juga menyuguhkan aspek ilmu nahwu dalam setiap penafsiran terhadap ayat-ayat al-Qur'an. Selain itu, al-Zajjāj juga menyuguhkan argumentasi kuat dalam berdialog terhadap karya-karya para ahli tafsir terdahulu yang telah menulis makna-makna al-Qur'an. Meskipun demikian, sebuah karya ilmiah memang butuh untuk dikritisi, ini yang dilakukan oleh Abu Alī al-Fārisī yang mengkritisi al-Zajjāj ketika melakukan tarjīh yang berbeda dengan pendapat yang lebih unggul. ${ }^{23}$

Dalam menjelaskan makna al-Qur'an, al-Zajjāj seringkali menyuguhkan berbagai pendapat lalu ia memilih pendapat yang paling kuat (tarjihh) dengan memberi argumentasi. Hal ini bisa dilihat ketika alZajjāj menafsirkan QS. al-Baqarah: 269. Kata yu'tī (mendatangkan) oleh al-Zajjāj dimaknai dengan yu'țī (memberikan). Sementara pemilihan makna yang terdapat tarjih adalah maksud kata hikmak mempunyai dua makna, pendapat pertama memberi makna kenabian. Sementara pendapat kedua memaknai dengan dengan al-Qur'an. Lantas al-Zajjāj menyatakan bahwa makna al-hikmah adalah al-Qur'an lebih unggul, karena dengannya bisa menjadikan ulama dari masa ke masa. Al-Qur'an bisa menjadi sarana untuk mendapat ilmu pengetahuan yang dapat memperdekatkan diri kepada Allah Swt. ${ }^{24}$

Al-Zajjāj juga memahami makna al-Qur'an dengan pendekatan ilmu qira'at. Hal ini bisa dilihat ketika menafsirkan kata al-arḥ̄mm dalam QS. alNisa': 1. Menurutnya, qira'at yang baik adalah dibaca wa al-arḥama (dibaca nasab, difathah pada huruf akhir, dan di'atafkan pada lafal Allah), dengan makna dan takutlah pada pada hubungan kekeluarganaan, jangan sampai terputus. Menurut al-Zajjāj bisa al-arḥām dibaca kasrah, maka bacaan itu salah dalam kaidah bahasa Arab, kecuali apabila terpaksa

22 al-Farrā', 100.

${ }^{23}$ Abu Ishaq al-Zajjāj, Ma'ānī al-Qur'ān wa I'rābuhu (Beirut: 'Alam al-Kutub, 1988),

6.

${ }^{24}$ al-Zajjāj, 159. 
dalam bacaan syiir. Pendapat al-Zajjāj ini tentu bertentangan dengan tokoh ilmu qira'at lainnya, karena menurut mereka lafaz wa al-arhām, bisa dibaca fathah (dibaca nașab) di'atafkan kepada Allah, bisa dibaca kasrah di'atafkan kepada lafaz bihi, dan juga bisa dibaca dhammah sebagai dhammah sedangkan khabarnya dibuang. ${ }^{25}$

Sejatinya, karya tentang Ma'ani al-Qur'an bukan sebatas pada karya tokoh al-Farrā', al-Zajjāj dan al-Naḥhās semata, namun sudah ada sejak Ḥamzah al-Kisā'î. Ia merupakan salah seorang tokoh linguistik Arab yang sangat concern serta mempelajari secara komprehensif bahasa al-Qur'an dalam kaitannya dengan kritik susastra Arab. Hal ini dibuktikan dengan adanya kutipan dan kesamaan pendapat yang sering dilakukan oleh Sibawaih kepada karya-karya al-Kisā'ī. Analisis gramatika yang dilakukan al-Kisā'î tentang makna al-Qur'an menjadikannya sebagai tokoh sentral era klasik yang banyak dirujuk oleh tokoh linguistik Arab era selanjutnya.

Dengan demikian, hasil karya $M a^{\prime} a \bar{n} \bar{\imath}$ al-Qur'ān baik yang dilakukan oleh al-Farrā', al-Zajjāj dan al-Naḥhās, bahkan sebelumnya dilakukan oleh al-Kisā'î dan al-Akhfasy menunjukkan concern mereka terhadap teori makna dalam al-Qur'an dalam perspektif filologi. Kajian linguistik Arab dalam memaknai al-Qur'an ini kemudian diteruskan oleh Ibu Qutaibah (w. 276 H) dengan karyanya yang berjudul Ta'wil Musykil al-Qur'an. Ibnu Qutaibah banyak meneliti makna al-Qur'an dan menyingkap rahasia dan keistimewaannya. ${ }^{26}$ Dalam karyanya tersebut ia membantah sementara kalangan yang menyatakan bahwa ayat-ayat al-Qur'an susah dipahami maknanya karena didalamnya terdapat kemusykilan. Selain itu Ibnu Qutaibah mengungkap makna bahasa al-Qur'an dalam ruang lingkup gramatikal Arab. ${ }^{27}$

Kajian makna al-Qur'an sejak al-Kisai hingga Ibnu Qutaibah menunjukkan adanya sumbangsih perpaduan keilmuan antara konstruksi ilmu linguistik Arab dengan kajian pemaknaan terhadap ayat-ayat al-Qur'an. Selain itu juga muncul kesadaran pada era klasik ini untuk semakin memahami ayat al-Qur'an melalui kajian linguistik Arab. Upaya

25 al-Zajjāj, 180.

${ }^{26}$ Syamsul Wathani, “TA'WIL MUSYKIL AL-QUR'AN KARYA IBN QUTAYBAH," Jurnal Al-Irfani: Jurnal Kajian Tafsir Hadits 1, no. 1 (2015): 75-102.

27 Ibnu Qutaibah Al-Dainūrī, Ta'wīl Musykil al-Qur'ān (Makkah: Maktabah alIlmiyah, 1987), 21.

JURNAL THEOLOGIA — Volume 31, Nomor 1, Juni 2020 
mereka dalam menelurkan karya-karya tersebut menjadi bukti bahwa keindahan gaya bertutur al-Qur'an mulai bersemai sejak era mereka dan akan terus berlangsung hingga akhir zaman. Karya-karya itu kemudian menjadi rujukan setiap pengkaji al-Qur'an yang ingin memahami makna al-Qur'an dari segi linguistik Arab.

\section{Teori Makna dalam Stilistika al-Qur'an}

Dalam realitas sejarah penafsiran klasik, para tokoh dibidang linguistik Arab telah banyak menyusun karya-karya dibidang gaya bahasa al-Qur'an atau yang biasa dinamakan dengan stilistika al-Qur'an. Mereka berupa meneliti secara masif nilai fasahah melalui diskursus ilmu uslub atau stilistika. Disamping itu, kajian tentang teori makna dalam al-Qur'an memberi bukti adanya relasi yang kuat antara teori linguistik Arab dengan ayat-ayat al-Qur'an sebagai teks (nașș). Wacana ini semakin berkembang di dalam khazanah keilmuan klasik dalam lingkup hubungan antara kalimat dengan makna kalimat serta hubungan kata dengan makna kata. ${ }^{28}$

Dalam kajian susastra Arab, wacana munculnya stilistika (ilmu uslūb) berawal dari apresiasi para pakar linguistik terhadap pidato dan puisi, kemudian berkembang pada kajian aspek-aspek kebahasaan makna dalam al-Qur'an. Hal ini memunculkan banyak definisi oleh para pengkaji ilmu al-Qur'an. ${ }^{29}$ Semisal al-Zarqānī, ia mendefinisikan stilistika (uslūb) al-Qur'an cara berbicara yang digunakan penutur (Allah) dalam menyusun kata-kata dan memilih kalimat yang indah, karena sejatinya alQur'an menggunakan keindahan gaya bahasa khusus yang tidak digunakan oleh cara bertutur manusia pada umumnya. ${ }^{30}$ Sementara stilistika menurut pengertian linguistik umum adalah cara-cara khas sesuatu dalam penuturan, diungkapkan dengan cara khusus sehingga arah tujuan yang dikehendaki bisa digapai dengan maksimal.

Menurut Ibnu Qutaibah, gaya bahasa (uslüb) ditentukan oleh kesesuaian konteks (siyāq), tema (maudlū') dan penutur (mutakallim).

\footnotetext{
${ }^{28}$ Setiawan, Akar-Akar Pemikiran Progresif dalam Kajian al-Qur'an, 79.

${ }^{29}$ Muhammad Alghiffary, "Makna Rahasia Wahyu Pertama (Kajian Stilistika AlQur'an)," IJAS: Indonesian Journal of Arabic Studies 1, no. 1 (2019): 1-17.

${ }^{30}$ Muhammad 'Abd al-'Aẓīm al-Zarqānī, Manāhil al-'Urfan fi 'Ulum al-Qur'an (Beirut: Dar al-Kutub al-'Ilmiyyah, 2010), 443.
} 
Bagi Ibnu Qutaibah, gaya bahasa adalah serangkaian daya penuturan kata atau kalimat yang berhubungan erat dengan tujuan tertentu dari berbagai tujuan penuturannya. Sehingga, langkah pertama dari gaya bahasa adalah penentuan serangkaian makna kemudian memilih metode yang sesuai dengan penggabungan pelbagai kosakata sehingga dapat menyampaikan pemikiran yang ada dalam benak orang yang bertutur. ${ }^{31}$

Karya susastra yang menjelaskan tentang gaya bahasa dan makna adalah kitab Bayān I'jāz al-Qur'ān, karya al-Khațțābī (w. 388 H). Menurut al-Khațāāi, banyak gaya bahasa yang disebabkan berubah-ubahnya tujuan. Begitu pula dalam gaya baha al-Qur'an, mengikuti perubahan cara atau metode yang biasa dipergunakan oleh penuturnya. ${ }^{32}$ Sementara itu, al-Baqilānī (w. $403 \mathrm{H}$ ) mempunyai pandangan yang berbeda, menurutnya gaya bahasa merupakan cara tersendiri yang ditempuh oleh setiap penuturnya. Lebih lanjut, gaya bahasa sangat berhubungan dengan jenis dan genre susastra. Oleh karena itu, al-Qur'an menggunakan gaya bahasa khas yang tidak sama dengan gaya sastra komunitas Arab pada umumnya. Susunan al-Qur'an termasuk unsur $\bar{j} j \bar{a} z$, berbeda dengan susunan tuturan masyarakat Arab ketika berbicara. ${ }^{33}$

Dalam I'jāz al-Qur'ān al-Baqilānī menyatakan bahwa keindahan susunan ayat-ayat al-Qur'an memuat pelbagai aspek kemukjizatan. Sebagiannya merujuk kepada kalimat, dalam artian susunan al-Qur'an dengan pelbagai alirannya tidak sama dengan tata urutan dan sistem yang sudah dikenal secara umum oleh masyarakat Arab. Al-Qur'an sebagai kalam Ilahi memiliki gaya bahasa (uslüb) yang khas yang berlainan dengan gaya bahasa tuturan manusia. Al-Qur'an tidak sama dengan syi'ir dan tidak sama pula dengan sajak. Karena berbeda dengan semua jenis tuturan dan gaya bahasa umumnya manusia, maka al-Qur'an disebut mukjizat. Masyarakat Arab tidak mempunyai tuturan yang mencakup fașāḥah, gharābah, ïjāz (makna luas dengan lafal singkat dan lain-lain. ${ }^{34}$

Teori aliran klasik tentang gaya bahasa (uslüb) bisa dianalis dari teori yang disampaikan oleh al-Jāhiz (w. 255 H). Menurut al-Jāhiz makna

31 Syihabuddin Qalyubi, Stilistika al-Qur'an: Makna di Balik Kisah Ibrahim (Yogyakarta: LKiS, 2009), 11.

32 Setiawan, Akar-Akar Pemikiran Progresif dalam Kajian al-Qur'an, 80.

${ }^{33}$ Qalyubi, Stilistika al-Qur'an: Makna di Balik Kisah Ibrahim, 13.

34 Manna' Khalīl al-Qațtān, Mabāḥis fi 'Ulūm al-Qur'ān (Cairo: Maktabah alTaufiqiyah, 2000), 380. 
merupakan suatu yang nampak pada benak pikiran seseorang, terbangun sedemikian rupa, serta disimpan oleh sanubari manusia yang terdalam, tersebunyi sehingga tidak dapat dipahami oleh orang lain dari pemilik makna melainkan dengan menggunakan perantara (wasilah). Perantara ini dapat berupa symbol bunyi bahasa yang disepakati dan ditulis dalam kelompok masyarakat tertentu. Dalam linguistik modern, bahasa sebagai alat komunikasi, baik yang tertulis maupun yang tidak disebut dengan kode. Al-Jāhiz menyebut 5 (lima) bentuk kode komunikasi, 1] lafaz atau kata, 2] tanda atau isyarah, 3] konvensi atau 'aqd, 4] kondisi tertentu atau hal, dan 5) nisbah. ${ }^{35}$

Dalam kajiannya terhadap makna dalam ayat al-Qur'an al-Jāhiz menemukan betapa pemilihan kosa kata yang dipergunakan al-Qur'an dalam memilih makna sangatlah indah, ini tidak akan bisa didapati dalam syi'ir Arab masa Jahiliyah, dalam Mu'allaqāt, maupun syiir pada masa Islam. Menurul al-Jāhiz al-Qur'an tidak pernah memiliki karakter tutur yang tidak pernah sia-sia, meskipun terdapat pengulangan (repetisi). Sebagai missal, kosa kata mathar dan ghaits yang keduanya memiliki arti hujan dalam bahasa kita. Menurut al-Jāhiz keduanya bukan sinonim karena masing-masing mempunyai karakter tersendiri, karena lafal mathar dalam al-Qur'an senantiasa dimaknai al-Qur'an dengan hujan yang dihubungkan dengan siksa. Sedangkan makna al-ghais dalam alQur'an selalu disandingkan dengan rahmat llah. ${ }^{36}$

Sementara menurut Abd al-Qāhir al-Jurjānī (w. 471 H) gaya bahasa al-Qur'an dalam hal ini nadzm mempunyai beberapa ciri khas. ${ }^{37}$ Pertama, nazhm ialah hubungan antara unsur-unsur yang terdapat pada kalimat. Kedua, kata dalam nazhm mengikuti makna. Kalimat dapat tersusun dalam tuturan karena maknanya telah tersusun lebih awal dalam jiwa sanubari. Ketiga, dalam keadaan terpisah, beberapa huruf yang berkolaborasi dengan makna punya karakter sendiri, agar makna mempunyai kekhususan. Keempat, kata bisa berubah dalam bentuk nakirah, ma'rifat, ada taqdīm dan ta'khïr, dan pengulangan (takrār).

${ }^{35}$ Setiawan, Akar-Akar Pemikiran Progresif dalam Kajian al-Qur'an, 80-81.

${ }^{36}$ Setiawan, 82.

${ }^{37}$ Ach Thabrani, "NADZAM DALAM I'JAZ AL QURAN MENURUT ABDUL QAHIR AL JURJANI," Al Mi'yar: Jurnal Ilmiah Pembelajaran Bahasa Arab dan Kebahasaaraban 1, no. 1 (2018): 1-14. 
Kelima, keistimewaan kata tidak dalam hal sedikit banyaknya makna, akan tetapi dalam kapasitasnya sesuai dengan makna dan tujuan yang diinginkan kalimat. ${ }^{38}$

Stilistika al-Qur'an akan sulit dipahami apabila hanya dipaparkan dalam sebuah teori belaka dan menyertakan contohnya. Al-Jurjani memberikan contoh cara kerja yang cermat dari konsep stilistika alQur'an sebagai berikut. Semisal, dalam QS. Maryam: 4, wasyta'ala al-ra's syaiban (kepalaku telah ditumbuhi uban). Menurut al-Jurjānī, dari sisi makna, lafaz isyta'ala (lebat/menyala) berkaitan dengan kata syaiban (uban) meskipun secara struktur makna berhubungan dengan kata al-ra's (kepala). Sebagai pembanding, kalimat yang berbunyi țāba zaidun nafsan. Dari segi makna, kata țāba (wangi) terkait dengan lafaz nafs (badan) meskipun secara struktural kata ini terkait erat dengan lafaz zaid. ${ }^{39}$

Apabila dicermati, keindahan terletak pada bunyi ayat dalam QS. Maryam: 4 tersebut tidak akan ditemukan pada susunan kalimat, semisal isyata'ala syaib al-ra'si (menyala/lebat uban kepala, atau lafal isyata'ala al-syaib fi al-ra's (uban menyala/lebat di kepala). Begitu juga apabila dianalisis secara cermat cara kerja stilistika pada ayat tersebut didapati di samping adanya makna uban mengkilap di bagian kepala, juga memuat makna mencakup seluruh bagian kepala dalam volume yang banyak sehingga tak sehelai pun rambut hitam tumbuh. Pengertian makna semisal ini tidak didapati dalam kalimat isyta'ala syaib al-ra'si atau isyta'ala al-syaib fi al-ra's, karena makna uban yang banyak itu tidak nampak pada dua kalimat tersebut. ${ }^{40}$

Stilistika yang menggunakan kata tanya (istifhām) juga menjadi perhatian al-Jurjani. Sub tema istifhām ini hampir selalu menjadi diskusi menarik para tokoh linguistik Arab. Hal yang didiskusikan tidak sebatas gramatik normatif, namun juga pada kajian sastra dalam kaitannya dengan pemaknaan ayat al-Qur'an. Dalam hal ini al-Jurjānī memberlakukan istifhām sebagai bagian dari bagian struktural yang bisa dipergunakan untuk menyamakan serta menentukan struktur kalimat yang tidak sama. Al-Jurjani juga menempatkan istifhām setingkat dengan

\footnotetext{
${ }^{38}$ Qalyubi, Stilistika al-Qur'an: Makna di Balik Kisah Ibrahim, 14-15.

${ }^{39}$ Qalyubi, 14.

${ }^{40}$ Qalyubi, 15.
} 
pembahasan tentang taqdim wa ta'khir (susun balik). Menurut al-Jurjani istifhām memungkinkan untuk untuk digabungkan dengan taqdim wa ta'khir berupa isim (kata benda) maupun fi'il (kata kerja) dalam sebuah kalimat dengan tujuan memperindah penuturan. Keindahan bahasa tersebut masih bisa ditambah fungsi lain, yaitu mengaktualisasikan makna. ${ }^{41}$

Al-Jurjānī menyuguhkan contoh al-Qur'an berkaitan model istifhām yang berimplikasi pada keindahan penuturan dan makna. Semisal dalam QS. al-Anbiyā': 62, a-anta fa'alta hāżà bi'ālihatinā yō Ibrahīm? "apakah engkau yang melakukan perbuatan ini terhadap tuhan-tuhan kami, Ibrahim? Menurut al-Jurjānī, pertanyaan seperti dalam ayat ini tidak bisa dimaknai laiknya bahasa Arab keseharian untuk menguatkan apakah Ibrahim yang melakukan pengrusakan sesembahan mereka itu ataukah tidak. ${ }^{42}$ Sebaliknya, pertanyaan model ini dalam konteks pembicaan ayat al-Qur'an merupakan penegasan bagaimana sesembahan-sesembahan mereka tersebut dihancurkan.43

Model kajian gaya bahasa (stilistika) adalah peralihan makna dalam sebuah kosa kata. Dalam wacana slitistika klasik peralihan makna juga ini menjadi perhatian Ibnu Qutaibah tatkala memahami makna kata 'kufr', tidak bertuhan. Menurutnya makna dasar kafara adalah menutupi dan melindungi. Dalam bahasa Arab, orang yang menutupi sesuatu disebut kafarahu. Dalam konteks yang lain kuffär bermakna petani. Hal ini ditemukan dalam QS. al-Ḥadīd: 20, kamaśali ghaisin a'jaba al-kuffāra, seperti air hujan yang tanam-tanamnya mengagumkan para petani. ${ }^{44}$ Sehingga makna kuffär tidak hanya berkonotasi sebagai orang yang tidak beriman, namun juga terkadang mempunyai arti petani, tukang batu atau ahli bangunan. Sementara, pemilihan kata ghais dalam ayat ini bermakna rahmat, sebagaimana yang telah dijelaskan al-Jāhiz di atas.

\section{E. Teori Makna dalam Semantik al-Qur'an}

Kajian teori makna terakhir dalam artikel ini adalah semantik, sebuah kajian yang berhubungan dengan makna kata. Lyons menjelaskan

${ }^{41}$ Setiawan, Akar-Akar Pemikiran Progresif dalam Kajian al-Qur'an, 86.

${ }^{42}$ Setiawan, 87.

43 Thabrani, "NADZAM DALAM I'JAZ AL QURAN MENURUT ABDUL QAHIR AL

${ }^{44}$ Setiawan, Akar-Akar Pemikiran Progresif dalam Kajian al-Qur'an, 84-85. 
bahwa semantik adalah menyelidikan terhadap makna kata-kata. Sejak zaman linguistik kuno, para pengkaji lebih tertarik dengan kajian makna kata-kata daripada kajian fungsi sintaksisnya. ${ }^{45}$ Semantik juga merupakan kajian tentang hubungan antara symbol bahasa (kata, frase, dan ekspresi) dan hubungannya dengan maka, serta konsep pemaknaan yang terdapat di dalamnya. Sebagian pakar yang lain menjelaskan bahwa semantik bukan hanya kajian tentang makna kata, namun juga merambah pada bidang kajian berbagai aspek struktur dan fungsi bahasa, sehingga kajian ini berhubungan dengan berbagai ilmu lain seperti filsafat, psikologi, dan antropologi. ${ }^{46}$

Dalam kajian makna al-Qur'an, semantik dianggap sebagai salah satu cara terbaik untuk menyingkap makna bahasa dan pencarian perubahan makna. Apabila bahasa adalah serangkaian kosa kata yang memuat makna dan merujuk pada objek tertentu, maka diperlukan metode untuk bisa menyingkap makna yang berada dalam kosa kata tersebut. ${ }^{47}$ Begitu juga, apabila ayat-ayat al-Qur'an agar dapat dipahami maknanya maka dibutuhkan serangkain metode untuk dapat menguak makna yang terkandung. Oleh para ulama, disusunlah ilmu balaghah, yang di dalam terdapat ilmu ma'ani. Dalam kajian al-Qur'an semantik juga erat hubungannya dengan ilmu munāsabah, al-wujūh wa al-nażāir, siyāq dan ilmu lain yang berkaitan dengan hubungan penyusunan kata dengan makna.

Semantik al-Qur'an pada kajian ini hanya diarahkan pada pembahasan al-wujūh wa naẓāir dan siyāq dalam al-Qur'an. Para era klasik, kajian wujūh dan naẓāir merupakan ikhtiyar dari tokoh linguistik bahasa Arab untuk memahami pesan makna yang dimiliki oleh kosa-kata yang dipakai dalam ayat-ayat al-Qur'an. Sedangkan siyāq merupakan indikator yang dipergunakan untuk menetapkan makna yang dikehendaki oleh pembicara atau penutur. Pada pembahasan selanjutnya akan diurai masing-masing kajian antara al-wujūh wa al-naẓāir dan siyāq

45 John Lyons, Introduction to Theoretical Linguistics (New York: Cambridge University Press, 1998), 44.

46 Mansoer Pateda, Semantik Leksikal (Jakarta: PT Rineka Cipta, 2004), 3.

${ }^{47}$ Fauzan Azima, "Semantik Al-Qur'an (Sebuah Metode Penafsiran)," TAJDID: Jurnal Pemikiran Keislaman Dan Kemanusiaan 1, no. 1 (2017): 45-73. 
beserta contohnya agar bisa dipahami dalam kerangka pemaknaan terhadap makna al-Qur'an.

Al-wujūh merupakan jama' dari kata al-wajh, Quraish Shihab menjelaskan bahwa al-wujūh merupakan kata yang sama secara utuh, dalam huruf dan bentuknya, yang didapati dalam pelbagai redaksi ayat, namun beraneka ragam makna yang terkandung di dalamnya. ${ }^{48} \mathrm{Al}$-nazāir menurut Ibnu al-Jauzī merupakan makna bagi satu kata dalam satu ayat sama dengan makna tersebut pada ayat yang lain, meskipun menggunakan kata yang lain.49 Dalam kitab al-Itqān al-Suyūțī (w. $911 \mathrm{H}$ ) menyatakan al-Naẓāir merupakan kosa kata yang saling berkaitan. ${ }^{50}$ Ada yang berpendapat bahwa naẓāir (kemiripan) yang terdapat pada lafal, sedangkan al-wujūh (keragaman) yang ada pada makna seperti kata ummah. Dengan demikian, al-nazāiir serupa dengan mutarādif dan alwujūh serupa dengan musytarak. Ringkasnya, al-wujūh berkaitan dengan perbedaan makna, sementara al-nazāair berpekaitan dengan perbedaan kosa kata. ${ }^{51}$

Meskipun sementara ulama menyamakan antara al-Nazāair (serupa) dengan mutarādif (sinonim), namun menurut Quraish Shihab terdapat perbedaan pada keduanya. Perbedaan itu terletak pada kedalaman analisis. Semisal, apabika dikatakan bahwa Insān (manusia) serupa dengan basyar (manusia) secara mutarādif, maka kita sekedar berhenti di sana, tanpa menganalisa sejauh mana kesamaan dan perbedaannya. Dari sisi nazāirnya maka analisa tentang kesamaan dan perbedaan kata itu harus ditekankan.

Berpagi-pagi al-Suyūṭī menguraikan bahwa ulama salaf yang memperkenalkan pembahasan tentang al-wujūh dan al-nazāair adalah Muqātil bin Sulaimān (w. 150 H) dalam karyanya al-Wujūh wa al-Nażāir fi al-Qur'an, dan dikembangkan oleh generasi ulama khalaf seperti Ibnu al-Jauzī (w. 597 H) dengan karyanya Nuzhah al-A'yun al-Nawāẓir fì 'Ilm al-

\footnotetext{
${ }^{48}$ M. Quraish Shihab, Wawasan Al-Qur'an (Bandung: Mizan, 1996), 125.

49 Jamaluddin Ibnu al-Jauzī, Nuzhah al-A'yun al-Nawazīi fì 'Ilm al-Wujūh wa alNazāöir (Beirut: Muassasah al-Risālah, 1987), 48.

50 Jalāluddīn al-Suyūțī, al-Itqān fi 'Ulum al-Qur'an, vol. 2 (Beirut: Dar al-Kutub alIlmiah, 1996), 189.

51 Ahmad Atabik, "Perspektif Al-Syawkani Tentang Pentarjihan Perbedaan Penafsiran," Hermeneutik Jurnal Ilmu al-Qur'an dan Tafsir Vol. 11 No (2017): 157-75, https://doi.org/http://dx.doi.org/10.1234/hermeneutik.v1 li2.5525.
} 
Wujūh wa al-Naẓāir, Ibnu al-Damaghānī (w. 478 H) dengan karyanya Qāmūs al-Qur'ān aw Ișlāh al-Wujūh wa al-Naẓāir fi al-Qur'ān al-Karīm. Sebelumnya Ibnu al-Jauzī menjelaskan bahwa para ulama yang telah menelurkan karya di bidang al-wujūh wa al-Naẓāir selain yang disebut oleh al-Suyūṭī adalah al-Kalbī, Abu al-Fadl al-'Abbās bin al-Fad\}l al-Anșārī, Abū Bakar bin Muḥammad bin al-Ḥasan al-Naqqāsy, Abū 'Alī al-Bannā', Abū al-Ḥasan 'Alī al-Zaghūnī.

Perlu dijelaskan bahwa al-Nazāir al-Qur'āniyah di sini adalah lafal atau kalimat yang terdapat dalam al-Qur'an yang dikuatkan penafsirannya oleh ayat lainnya. Dinamakan al-Nazāair al-Qur'āniyah karena adanya kemiripan dan keterkaitan penafsiran dan pemahaman antara ayat satu dengan ayat lainnya. Al-Damaghani, dalam karyanya Qamus al-Qur'an memberi contoh, kata al-ajr dalam al-Qur'an mempunyai empak makna. 1) Al-ajr bermakna mahar, dalam QS. al-Ahzab: 50, Allātī ātaita ujūrahunna, kata ujūrahunna bermakna mahar-mahar mereka. 2) al-ajr bermakna pahala, dalam QS. al-Nahl: 96, ajrahum bermakna pahala mereka. 3) al-ajr bermakna upah, dalam QS. al-Qasas: 25, ajra ma, bermakna upah atas bantuan memberi minum, 4). Al-ajr bermakna nafkah, dalam QS. al-Talaq: 6, fa àtuhunna ujūrahunna, bermakna memberi nafkah.52

Pola semantik teori makna dalam kajian al-Qur'an juga ditemukan dalam pembahasan tentang siyāq. Ibnu Daqīq al-'Id mendefisinikan siyāq dengan makna yang menunjukkan pada maksud pembicaraan seseorang. Di sisi lain, Quraish Shihab menjelaskan bahwa siyāq adalah sebuah indikator yang dipergunakan untuk menetapkan makna yang dikehendaki oleh pembicara atau penyusun kata. Siyāq dalam fungsinya sebagai indikator terbagi menjadi dua; 1) Siyāq lughawī, maqālī atau konteks bahasa yaitu siyāq yang didasarkan pada rangkaian kalimat. 2) Siyāq ghair lughawī yaitu yang tidak dikaitkan dengan bahasa, biasanya dikaitkan dengan situasi yang meliputinya, atau disebut dengan siyāq alhăl atau konteks situasi. ${ }^{53}$

\footnotetext{
52 al-Husain bin Muhammad al-Damaghānī, Qamūs al-Qur'ān aw Islah al-Wujūh wa al-Nazāair fi al-Qur'ān al-Karīm (Beirut: Dār al-'Ilm li al-Malāyīn, 1983), 58.

${ }^{53}$ Shihab, Wawasan Al-Qur'an, 253.
} 
Al-Ṭayyār menjelaskan, dengan tafsir siyāqī ini, kalimat yang berada setelahnya lebih layak untuk disisihkan daripada keduanya kecuali dengan adanya dalil yang mengharuskan untuk menerimanya. Pendapat yang didukung oleh dalil di dalam siyāq lebih diutamakan daripada yang tidak didukung. ${ }^{54}$ Al-Syaukānī dalam menafsirkan alQur'an, acap kali dengan siyā $q$ bahasa serta mempertimbangkan konteks pembicaraannya. Hal inilah yang disebut dengan tafsir siyāqī (tafsir yang menitik beratkan pada konteks bahasa), yaitu memahami ayat dengan pertimbangan ayat atau kata sesudahnya atau sebelumnya sebagai kesatuan yang menggambarkan makna keseluruhan dari ayat tersebut.

Di antara mufasir yang memaparkan penafsiran dengan siyāq (konteks kalimat) adalah al-Syaukani. Sebagai contoh ketika al-Syaukānī dalam Fath al-Qadir, menafsirkan QS. al-Baqarah: 34. Al-Syaukānī menyuguhkan dua pendapat terkait dengan apakah sujudnya malaikat kepada Adam sebelum Allah mengajarinya nama-nama benda (musammayāt) atau setelahnya. Al-Syaukānī mentarjịh, konteks ayat menunjukkan bahwa Allah mengajari Adam nama-nama benda (musammayāt), kemudian disusul perintah sujud, selanjutnya Allah menempatkannya di surga, lalu mengeluarkannya dari surga dan menempatkannya di bumi. Lantas, mengapa berdasarkan siyāq al-Qur'ān al-Syaukānī mengunggulkan pendapat kedua ini?55 Pentarjīhan alSyaukānī terhadap siyāq nampaknya menggunakan redaksi yang hampir sama dengan pentarjīhannya terhadap zāhir al-Qur'ān. Ia tidak berpanjang lebar dalam menyuguhkan berbagai pendapat itu.

Dari sini pentinglah seseorang yang ingin memahami makna dari ayat-ayat al-Qur'an harus mengetahui konteks ayat. Banyak orang bahkan melakukan kesalahan dalam melakukan penafsiran ayat karena tidak memperhatikan konteks serangkaian ayat yang dipahami. Sebagaimana juga orang akan bisa salah memahami makna kosa kata dalam al-Qur'an apabila tidak merujuk pada kajian al-wujuh wa al-naẓāir, menimbang bahasa Arab merupakan bahasa yang kaya akan makna kosa kata yang tidak dimiliki oleh bahasa lain. Apalagi al-Qur'an merupakan mukjizat

${ }^{54}$ Musā'id bin Sulaimān al-Ṭayyār, Fusūl fì Usūl at-Tafsīr (Riyad: Dār al-Nasyr alDaulī, 1993), 101.

55 Muhammad bin Ali al-Syaukānī, Fatḥ al-Qadīr al-Jāmi' baina Fannai ar-riwāyah wa ad-dirāyah min 'ilm at-Tafsīr, vol. 1 (Beirut: Dār Ibn Hazm, 2014), 162. 
yang tidak bisa ditandingi penyusunannya oleh siapapun orangnya dimuka bumi ini. Inilah pentingnya kajian semantik al-Qur'an untuk mengetahui makna dari pelbagai ayat al-Qur'an.

\section{F. Kesimpulan}

Pada era klasik diantara kajian yang menjadi konsentrasi para tokoh pengkaji al-Qur'an adalah pemahaman makna al-Qur'an dengan pendekatan linguistik Arab. Lebih spesifik lagi mereka mencurahkan perhatian pada i'rab (gramatika bahasa Arab) untuk mendapatkan pemahaman makna ayat. Pada masa klasik ini bermunculan secara masif para pengkaji al-Qur'an yang concern dalam bidang kritik bahasa untuk mendapatkan makna ideal dari ayat al-Qur'an, melalui pendekatan gramatika, stilistika maupun semantik. Kajian linguistik makna al-Qur'an masa klasik ditopang dengan maraknya aliran linguistik Arab, terutama Mazhab Basrah dan Kufah.

Teori makna pada masa klasik ditopang dengan pelbagai karya para pakar linguistik Arab klasik yang berjudul Ma'ānī al-Qur'ān. Karyakarya ini sangat signifikan dalam perkembangan teorisasi makna dari sudut pandang struktuk bangunannya (gramatikal bahasa). Setidaknya ada 4 (empat) karya berjudul Ma'ānī al-Qur'ān pada era klasik ini. Ma'ānī al-Qur'ān karya al-Kisā'ī, karya al-Farrā', karya al-Zajjāj, dan karya alNaḥhās. Teori makna juga ditopang oleh kajian stilistika al-Qur'an masa klasik. Al-Khiț̣ābī dalam karyanya Bayān I'jāz al-Qur'ān menjelaskan tentang gaya bahasa (stilistika/uslüb) yang digunakan al-Qur'an dalam menentukan makna yang dikehendaki oleh penuturnya (Allah). Kajian stilistika al-Qur'an dalam teori makna ini juga dikuatkan al-Jāhiz dan alJurjānī dalam karya mereka masing-masing.

Sedangkan, teori makna yang terakhir juga dapat ditemukan dalam kajian semantik. Kajian ini dianggap sebagai metode ideal dalam menyingkap makna bahasa al-Qur'an. Kajian al-Qur'an semantik erat hubungannya al-wujūh wa al-naz̄āir dan, siyāq (konsteks makna bahasa). Kajian Wujūh dan nazāiir merupakan metode memahami pesan makna yang dimiliki oleh kosa-kata ayat al-Qur'an, kajian ini pernah diperdalam oleh Ibnu al-Jawzī dalam karyanya Nuzhat al-A'yun. Sementara siyāq merupakan indikator yang dipakai dalam menetapkan makna yang 
dikehendaki oleh mutakallim, pernah menjadi concern Ibn Daqīq al-Id dalam karyanya Ihkām al-Aḥkām.

\section{REFERENCE}

Al-Dainūrī, Ibnu Qutaibah. Ta'wīl Musykil al-Qur'ān. Makkah: Maktabah alIlmiyah, 1987.

al-Damaghānī, al-Husain bin Muhammad. Qamūs al-Qur'ān aw Islah alWujūh wa al-Nazāir fi al-Qur'ān al-Karīm. Beirut: Dār al-'Ilm li alMalāyīn, 1983.

al-Farrā', Abū Zakariyā Yahyā bin Ziyād. Ma'ānī al-Qur'ān. Beirut: 'Alam al-Kitab, 1983.

al-Jauzī, Jamaluddin Ibnu. Nuzhah al-A'yun al-Nawaẓir fì 'Ilm al-Wujūh wa al-Naẓā'ir. Beirut: Muassasah al-Risālah, 1987.

al-Qațțān, Manna' Khalīl. Mabāḥis fi 'Ulūm al-Qur'ān. Cairo: Maktabah alTaufiqiyah, 2000.

al-Suyūțī, Jalāluddīn. al-Itqān fi 'Ulum al-Qur'an. Vol. 2. Beirut: Dar alKutub al-Ilmiah, 1996.

al-Syaukānī, Muhammad bin Ali. Fatḥ al-Qadīr al-Jāmi' baina Fannai arriwāyah wa ad-dirāyah min 'ilm at-Tafsīr. Vol. 1. Beirut: Dār Ibn Hazm, 2014.

al-Ṭayyār, Musā'id bin Sulaimān. Fusūl fì Usūl at-Tafsīr. Riyad: Dār alNasyr al-Daulī, 1993.

Al-Żahabī, Muhammad Husain. Al-Tafsīr wa al-Mufassirūn. Vol. 1. Cairo: Maktabah Wahbah, 1995.

al-Zajjāj, Abu Ishaq. Ma'ānī al-Qur'ān wa I'rābuhu. Beirut: 'Alam al-Kutub, 1988.

al-Zarqānī, Muhammad 'Abd al-'Aẓīm. Manāhil al-'Urfan fi 'Ulum al-Qur'an. Beirut: Dar al-Kutub al-'Ilmiyyah, 2010.

Alghiffary, Muhammad. "Makna Rahasia Wahyu Pertama (Kajian Stilistika 
Al-Qur'an)." IJAS: Indonesian Journal of Arabic Studies 1, no. 1 (2019): $1-17$.

Arifuddin, Arifuddin. "Pemikiran-Pemikiran Fonetik Ibnu Jinni (W. 392 H./1002 M.)." Jurnal CMES 6, no. 2 (n.d.): 146-63.

Atabik, Ahmad. "Corak Tafsir Aqidah (Kajian Komparatif Penafsiran Ayatayat Aqidah)." ESENSIA: Jurnal Ilmu-Ilmu Ushuluddin 17, no. 2 (2016): 209-23.

-_- "Perspektif Al-Syawkani Tentang Pentarjihan Perbedaan Penafsiran." Hermeneutik Jurnal Ilmu al-Qur'an dan Tafsir Vol. 11 No (2017): 157-75. https://doi.org/http://dx.doi.org/10.1234/ hermeneutik.v1 li2.5525.

Azima, Fauzan. "Semantik Al-Qur'an (Sebuah Metode Penafsiran)." TAJDID: Jurnal Pemikiran Keislaman Dan Kemanusiaan 1, no. 1 (2017): 45-73.

Aziz, Abd, dan Yuan Martina Dinata. "Bahasa Arab Modern Dan Kontemporer; Kontinuitas Dan Perubahan." Mumtaz: Jurnal Studi AlQuran dan Keislaman 3, no. 2 (2019): 152-68.

Faudah, Mahmud Basuni. Tafsir-Tafsir al-Qur'an: Perkenalan dan Metodologi Tafsir. terj. Mokhtar Zoerni dan Abdul Qadir Hamid. Bandung: Penerbit Pustaka, 1987.

Hidayatullah, Syarif. Cakrawal Linguistik Arab. Tangerang: al-Kitabah Press, 2012.

Ichwan, Nor. Memahami Bahasa al-Qur'an: Refleksi atas Persoalan Linguistik. Yogyakarta: Pustaka Pelajar, 2002.

Lyons, John. Introduction to Theoretical Linguistics. New York: Cambridge University Press, 1998.

Mahmūd, Manī’ Abd al-Ḥalīm. Manhaj al-Mufassirīn. Cairo: Dar al-Kitab alMasri, 2000.

Mukrim, 'Abd al-'Āl Sālim. Al-Qur'ān al-Karīm Wa As̄āruhu fi al-Dirāsāt alNaḥwiyah. Kuwait: Muassasah 'Alī Jarrāḥ al-Ṣabāḥ, 1978. 
Mustaqim, Abdul. 'Tafsir Linguistik (Studi atas Tafsir Ma'anil Qur'an Karya al-Farra')." QOF 3, no. 1 (2019): 1-11.

- - - "Teori Hudud Muhammad Syahrur dan Kontribusinya dalam Penafsiran al-Qur'an." AL QUDS: Jurnal Studi Alquran dan Hadis 1, no. 1 (2017): 1-26.

Pateda, Mansoer. Semantik Leksikal. Jakarta: PT Rineka Cipta, 2004.

Qalyubi, Syihabuddin. Stilistika al-Qur'an: Makna di Balik Kisah Ibrahim. Yogyakarta: LKiS, 2009.

Ridwan, Ridwan. "Karakteristik Nuhat Kufah Dan Bashrah." LiNGUA: Jurnal Ilmu Bahasa dan Sastra 3, no. 1 (2011).

Rohman, M Fathor. "Kajian Historis; Periodisasi Tokoh Ilmu Nahwu Madzhab Basrah." Ummul Qura 11, no. 1 (2018): 50-72.

Setiawan, M. Nur Kholis. Akar-Akar Pemikiran Progresif dalam Kajian alQur'an. Yogyakarta: Elsaq Press, 2008.

Shihab, M. Quraish. Kaidah Tafsir: Syarat, Ketentuan, dan Aturan yang Patut Anda Ketahui dalam Memahami Ayat-ayat al-Qur'an. Tangerang: Lentera Hati, 2013.

-_- Membumikan al-Qur'an. Bandung: Mizan, 1994.

- - Wawasan Al-Qur'an. Bandung: Mizan, 1996.

Tanjung, Abdurrahman Rusli. "Wawasan Penafsiran Alquran dengan Pendekatan Corak Lugawi (Tafsir Lugawi)." Journal Analytica Islamica 3, no. 2 (2014): 333-48.

Thabrani, Ach. "Nadzam Dalam I'jaz Al Quran Menurut Abdul Qahir Al Jurjani." Al Mi'yar: Jurnal Ilmiah Pembelajaran Bahasa Arab dan Kebahasaaraban 1, no. 1 (2018): 1-14.

Wathani, Syamsul. "Ta'wil Musykil Al-Qur'an Karya Ibn Qutaybah." Jurnal Al-Irfani: Jurnal Kajian Tafsir Hadits 1, no. 1 (2015): 75-102. 